\title{
Local People's Perceptions of Crop Damage by Common Langurs (Semnopithecus entellus) and Human-Langur Conflict in Keshabpur of Bangladesh
}

\author{
Ummay Habiba Khatun ${ }^{1}$, M. Farid Ahsan ${ }^{1}$ \& Eivin Røskaft ${ }^{2}$ \\ ${ }^{1}$ Department of Zoology, University of Chittagong, Chittagong-4331, Bangladesh \\ ${ }^{2}$ Department of Biology, Norwegian University of Science and Technology, Trondheim, Norway \\ Correspondence: Eivin Røskaft, Department of Biology, NTNU, Realfagbygget, No-7491 Trondheim, Norway. \\ Tel: 47-9065-2883. E-mail: roskaft@bio.ntnu.no
}

Received: October 26, 2012 Accepted: January 17, 2013 Online Published: January 20, 2013

doi:10.5539/enrr.v3n1p111 URL: http://dx.doi.org/10.5539/enrr.v3n1p111

\begin{abstract}
We studied crop damage and human-langur conflicts in six villages of Keshabpur upazila in the Jessore district of Bangladesh from September 2009 to August 2010. Data were collected by interviewing local people with a questionnaire. We discuss the attitudes of locals towards crop damage inflicted by the common langur (Semnopithecus entellus). We analysed local deterrent methods for reducing crop damage and the management strategy adopted by the Forest Department to conserve langurs. Thus, we investigated how demographic variables were associated with the perceptions of locals towards crop damage and conflicts. A total of 27 different crop species were cultivated across the villages, among which langurs mostly damaged fruits. Although most damage occurred during the fruiting season langurs damaged crops throughout the year. Around $55 \%$ of the respondents reported that the local deterring methods were effective but that they affect their children's education and economy. Furthermore, almost $59 \%$ of the respondents were tolerable towards the langur damage. People living in villages with a high langur population and where weak conservation methods were used reported greater crop damage than their counterparts. A linear regression analysis revealed that the occupation, landholding status, and ethical and religious beliefs of the people included in this study has a significant impact on their attitudes regarding conservation. Therefore, there is an urgent need to implement conservation measures to mitigate human-langur conflicts as well as to conserve common langurs in areas where humans and langurs coexist.
\end{abstract}

Keywords: common langur, human-langur conflict, crop raiding, Bangladesh, Hindus, Muslims

\section{Introduction}

Human-nonhuman primates (hereafter primates) conflicts are recognised as major issues in conservation of primates now-a-days. Crop damage caused by raiding primates' is one of the most widespread and common examples of human-primate conflicts in areas where local people are mainly subsistence farmers (Hill, 1998). Conflicts between humans and primates are increasingly emerging as people transform primate habitats into agricultural fields and because of many other anthropogenic activities occurring around the habitats of these species. In many parts of the tropics, primates and humans coexist. Concern is currently growing related to food and other needs of humans that have jeopardized the ability to live in close association with primates (Cowlishaw \& Dunbar, 2000; Hill, 2000). To date, crop raiding by wildlife including primates has received a great deal of attention in and around protected areas across Asia and Africa (Agetsuma, 2007; Chhangani \& Mohnot, 2004; Hill, 1997; Naughton-Treves, 1998; Pirta, Gadgil, \& Kharshikar, 1997; Riley, 2007; Saj, Sicotte \& Paterson, 2001; Sarker \& Røskaft, 2010; Sarker \& Røskaft, 2011b; Strum, 1994; Tweheyo, Hill \& Obua, 2005; Webber, Hill, \& Reynolds, 2007). Apart from the studies of crop raiding by wildlife, especially Asian elephants (Elephas maximus) around protected areas (Aziz, Feeroz, \& Shahriar, 2005; Feeroz, Aziz, Islam, \& Islam, 2003; Islam \& Al Zabed, 1992; Miah, Rahman, \& Ahsan, 2001; Sarker \& Røskaft, 2011a) no studies have been conducted on crop damage by primates in human settlements in Bangladesh. However, in Asia in general and Bangladesh in particular, conflicts between humans and the endangered common langurs (Semnopithecus entellus) are increasingly emerging (IUCN, 2009). However, there is no systematic records or centralized 
database recording such conflicts; thus, only a few verified cases are available for studying exactly what is taking place in these interactions and to what extent the conflicts overlap. Hence, it is important to document the level of conflicts between humans and common langurs for the purpose of adopting measures for the langur conservation in and around densely populated human habitats.

Crop raiding is an essential component of the ecology of primates inhabiting human settlements, but it makes their ability to cope with humans more difficult (Naughton-Treves, Treves, Chapman, \& Wrangham, 1998). When natural food is in short supply, high quality and easily digested human food is a good alternative form of nutrition for primates, which could be the most important cause of the intensity of crop raiding (Horrocks \& Baulu, 1994). Behavioural adaptability, intelligence, the nature of being opportunistic frugivorous and the general diets of some primates might enable them to exploit successfully agricultural crops in many tropical countries (Chivers, 1986; Gautier \& Biquand, 1994; Mittermeier \& Cheney, 1987). The species that are flexible in behaviour and able to adapt to human induced habitats are often compelled to come into direct competition with humans for food and shelter, and are perceived as significant crop pests (Siex \& Struhsaker, 1999). The habit of crop raiding, therefore, reduces tolerance towards the crop pests in question and might add another dimension of threat for species that are already endangered (Campbell-Smith, Simanjorang, Leader-Williams, \& Linkie, 2010).

Most primates are potential crop raiders across their habitats (e.g., olive baboons (Papio hamadryas anubis) (Forthman-Quick, 1996); vervet monkey (Chlorocebus aethiops) (Boulton, Horrocks, \& Baulu, 1996); Rhesus macaque (Macaca mulatta) (Pirta, Gadgil, \& Kharshikar, 1997); red-tailed guenon (Cercopithecus ascanius), blue monkey (Cercopithecus mitis) (Hill, 1997); Sumatran urangutan (Pongo abelii) (Campbell-Smith, Simanjorang, Leader-Williams, \& Linkie, 2010); chimpanzee (Pan troglodytes) (Reynolds, 2005); Eastern gorilla (Gorilla gorilla berengei), Western gorilla (Gorilla gorilla gorilla) (Hill, 2005; Hockings, 2007; Lahm, 1996); and bonobo (Pan paniscus) (Dupain \& Elsacker, 2001; Myers-Thompson, 2001)). They dominate the list of crop pests, particularly around the protected areas of Africa and Asia, being responsible for more than $70 \%$ of the occurred damage events and $50 \%$ of the area damaged (Naughton-Treves, 1998). Therefore, in tropical areas of high level of conservation concern, primates are perceived as significant pests (Horrocks \& Baulu, 1994). Such examples of crop raiding are likely to minimize the tolerance of subsistence farmers towards conservation of these threatened primate species. Although tolerance mostly depend upon the degree of the economic and/or social costs of the conflict, which the agricultural community suffers for crop damage (Campbell-Smith, Simanjorang, Leader-Williams, \& Linkie, 2010).

The common langur is classified as a folivorous primate (Ahsan \& Khan, 2006), although there are few formal records of crop raiding among the folivorous colobines. However, red colobus (Procolobus kirkii) raid immature coconuts of subsistence farmers in the island of Zanzibar (Siex \& Struhsaker, 1999); mantled guereza (Colobus guereza) raid field crops in Africa (Naughton-Treves, 1998); common langur (Semnopithecus entellus) raid cultivated crops in and around the Aravallis in India (Chhangani \& Mohnot, 2004); and purple-faced langur (Trachypithecus vetulus) is reported to damage human-edible crops in human-induced habitats of Sri Lanka (Dela, 2004; Dela, 2007).

This study was conducted in six villages (Keshabpur, Baliadanga, Brahmakati, Ramchandrapur, Durgapur, and Madhyakul) of the Keshabpur upazila (UP) (which means sub-district) in the Jessore district of Bangladesh from September 2009 to August 2010. The Upazila Keshabpur covers an area of $259 \mathrm{~km}^{2}$, which is the best potential habitat of the common langurs in Bangladesh. Predominately, this area was covered with vast homestead vegetation; now most of the area has been altered with increasing clearance of land for farming and new settlements. The subsistence farmers change their practices of crop pattern and plantation, i.e., planting much-valued crops and trees, and the langurs are facing challenges for food, shelter and safety. Therefore, the common langur is forced to overlap human niches in the area making a competition for resources. Such interactions make farmers community antagonistic and intolerant towards the langurs. Hence, it is vital to assess the farmers' perceptions towards crop damage by langurs and their impacts on crop fields as well as the tree crops to develop a mitigation strategy for langur conservation in the area.

The present study, therefore, provides data through interviews of local people regarding the magnitude of human-langur conflicts as well as human perceptions towards crop raiding langurs and suggestions for improvement of their conservation. We collected data for the purposes of (1) quantifying the extent of the conflict, (2) estimating the level of crop damage, (3) investigating people's attitudes towards langurs, and (4) examining how different socioeconomic variables influence people's attitudes and which variables are significantly associated with the conservation of common langurs. 


\section{Methods}

The Upazila Keshabpur is located approximately between latitudes $22^{\circ} 25^{\prime}$ to $23^{\circ} \mathrm{N}$ and longitudes $89^{\circ} 25^{\prime}$ to $89^{\circ} 38^{\prime} \mathrm{E}$. (Figure 1). In the north, the Manirampur UP bounds the Keshabpur UP, and in the south, it is bounded by the Tala and Dumuria UPs; the Dumuria UP covers the eastern area, while the Kalarua UP is situated to the west. The Keshabpur UP supports 37,576 households, with a density 1,120 people per $\mathrm{km}^{2}$, and $47.5 \%$ of the people in the UP are dependent on agriculture for their livelihood (BBS, 2009). The majority (80.1\%) of the population consists of Muslims, and most of the remaining people are Hindus (19.5\%), and only a small fraction $(0.4 \%)$ belongs to other religions. Ten agricultural crops and vegetables, 11 major fruit plants are being cultivated in the langurs holding areas of Keshabpur; five cereal crops were once abundant but now these are scarcely cultivated in the area (Anon, 2003).

We selected the aforementioned six villages because most of the common langurs in Bangladesh inhabit this area. Eleven free-ranging groups of common langurs have been observed in this area (Khatun, 2012). The respondents therefore had a good chance of encountering common langurs on a regular basis. In the Keshabpur UP, the governmental 'Biodiversity Conservation and Nature Development' project was initiated in June 2006 to supply provisional food for the langurs. Three villages included in this study are part of this government conservation program. In addition, local administration has planted a variety of fruiting trees in the UP following the implementation of the project to supply food and shelter to the langurs. Since 1979, the villagers in the area have been planting varieties of fruiting, non-fruiting (timber) and herbal trees under the governmental social afforestation scheme during the monsoon. However, the density of trees is not equal among the six villages (Khatun, 2012). Most of the langur groups (eight out of eleven) therefore lived in the villages where the availability of natural food and tree density was high. We categorized the study villages into the following two sites in relation to activities associated with langur conservation, the availability of natural food and the distribution of langur groups: (1) high status conservation area (Keshabpur, Baliadanga, and Brahmakati), which is relatively urban and close to the local administration headquarter where additional food is supplied twice a day, and visitors also occasionally provide small food items to the langurs; and (2) low status conservation area (Ramchandrapur, Durgapur, and Madhyakul), located relatively far away from the headquarter where the supplier provisions langurs two times in a week only (one or two groups only, because of the insufficient allocation of food).

\subsection{Data Collection}

Information on human-langur conflict was collected through administering questionnaire surveys in six villages of the Keshabpur UP in the Jessore district. Interviews were conducted using a questionnaire from September 2009 to August 2010. After a pre-test on ten people, a total of 410 individuals were randomly interviewed. Data were collected by one of the three authors (UHK) and/or three trained field assistants who were familiar with the local inhabitants.

First, we informed the interviewees of the aims and objectives of the study and attempted to make them feel confident about participating in the research, i.e., that any secrecy or personal views of respondents would not be revealed or not be included as results. The interviews were conducted with the household head, the wife of the household head or with resident adults ( $\geq 18$ years) who were willing to participate in an interview as a representative of the family. Each interview was conducted in the Bengali language. It took approximately 40-45 minutes to complete one questionnaire.

The questionnaire included a combination of closed-ended for example, yes or no or don't know, appropriate or poor) and open-ended questions and addressed background information on the respondents (age, gender, level of education, religion, and household size) and their socioeconomic status (occupation, land occupying status, and cultivated farm size in acres). We asked open-ended questions to evaluate the perceptions of the interviewees towards crop raiding langurs as well as the conservation of the species. The respondents were asked to rank how much different crop species were damaged, as rank 1 indicated the most damaged crop, rank 2 the second most damaged and so on until the least damaged crop.

\subsection{Statistical Analyses}

The crops were grouped into three categories based on economic value and as well as they were easily cultivable: (1) important crops (banana, mango, jackfruit, guava, jujube, papaya, bean (Vicia faba), brinjal (Solanum melongena); (2) intermediate crops [sapodilla, sweet hog plum and sour hog plum, jute, pulses, litchi, and cauliflower (Brassica campestris)]; and (3) unimportant crops [cabbage (B. capitata), black berry, tamarind, custard apple (Annona squamosa), pomelo (Citrus decumena), ladies finger (Abelmoschus esculentum), green chilli, horseradish tree (Moringa oleifera), betel leaf, tomato (Solanum lycopersicum), sesame and coconut]. The 
seasons we grouped into two categories: (1) fruiting season (March - July) and (2) throughout the year.

We used stepwise linear regression analyses to identify relationships between local perceptions and the different independent variables (Box 1). We used Pearson Chi-square tests to check for differences between the general responses of the respondents. All of the statistical analyses were executed using the Statistical Package for Social Sciences version 16, (SPSS, Chicago).

Box 1. Questions and answers addressed to the respondents

\begin{tabular}{|c|c|}
\hline Questions & Answers \\
\hline $\begin{array}{l}\text { a) What is your experience regarding human-langur } \\
\text { conflicts? }\end{array}$ & $\begin{array}{l}\text { 1) crop raiding, 2) household disturbance, } \\
\text { 3) miscellaneous }\end{array}$ \\
\hline $\begin{array}{l}\text { b) How important is the crop damage caused by } \\
\text { common langurs in your garden or agricultural field? }\end{array}$ & $\begin{array}{l}\text { 1) important, 2) intermediate, } \\
\text { 3) unimportant }\end{array}$ \\
\hline $\begin{array}{l}\text { c) During what season do the langurs damage the most } \\
\text { crops? }\end{array}$ & $\begin{array}{l}\text { 1) fruiting season = March-July, } \\
\text { 3) throughout the year }\end{array}$ \\
\hline $\begin{array}{l}\text { d) How do you drive away langurs from your } \\
\text { farmland? }\end{array}$ & $\begin{array}{l}\text { 1) guarding, 2) immediate, } \\
\text { 3) miscellaneous }\end{array}$ \\
\hline $\begin{array}{l}\text { e) Are the local methods used effective for deterring } \\
\text { langurs? }\end{array}$ & 1) yes, 2) no \\
\hline f) Do you tolerate crop damage by langurs? & 1) yes, 2) no \\
\hline $\begin{array}{l}\text { g) What is your opinion about the management } \\
\text { strategy adopted by the forest department to minimize } \\
\text { crop damage? }\end{array}$ & 1) poor, 2) appropriate \\
\hline
\end{tabular}

We referred to people who were living in the study villages as people/locals/villagers; individuals who were living in the same houses and sharing income as affinity relatives; and the fruits and crops that were growing in the villages as crops. Because we wanted to test the values given by the people we regarded the value "don't know" as missing values in the analyses all through.

\section{Results}

\subsection{Socioeconomic Profile of the Respondents}

The total number of respondents was 410, of whom 209 (51\%) were men, and 201 (49\%) women. The reported ages of the respondents ranged from $18-94$ years, and $41.7 \%$ were from small households, whereas $58.3 \%$ from large households. In addition, $57.4 \%$ were Muslims and $42.6 \%$ Hindus; and $62 \%$ had access to mass media, whereas $38 \%$ had no access. Regarding education and landholding status, $14.4 \%$ of the respondents had been to school, whereas $85.6 \%$ were uneducated; $31 \%$ had a high landholding status, $46 \%$ low status, and $23 \%$ were of intermediate landholding status. Finally, $61.2 \%$ were farmers, and $38.8 \%$ non-farmers (Table 1 ).

The socioeconomic profile of the respondents did not differ significantly among the villages in terms of gender $\left(\chi^{2}=9.6\right.$, d.f. $\left.=5, \mathrm{P}=0.083\right)$, age class $\left(\chi^{2}=6.2\right.$, d.f. $\left.=5, \mathrm{P}=0.283\right)$, household size $\left(\chi^{2}=6.9\right.$, d.f. $\left.=5, \mathrm{P}=0.221\right)$, access to mass media $\left(\chi^{2}=2.8\right.$, d.f. $\left.=5, \mathrm{P}=0.729\right)$, and education $\left(\chi^{2}=8.1\right.$, d.f. $\left.=5, \mathrm{P}=0.149\right)$. However, the socioeconomic variables differed significantly among the villages with respect to religion $\left(\chi^{2}=41.8\right.$, d.f. $=5, \mathrm{P}=$ $0.000)$, landholding status $\left(\chi^{2}=39.6\right.$, d.f. $\left.=10, P=0.000\right)$, and the occupation of the respondents $\left(\chi^{2}=16.8\right.$, d.f. $=5, \mathrm{P}=0.006$; Table 1$)$. 
Table 1. Socioeconomic profiles (in percentages) of the 410 respondents from the six studied villages in relation to gender, age, household size, religion, access to mass media, education, landholding status and occupation

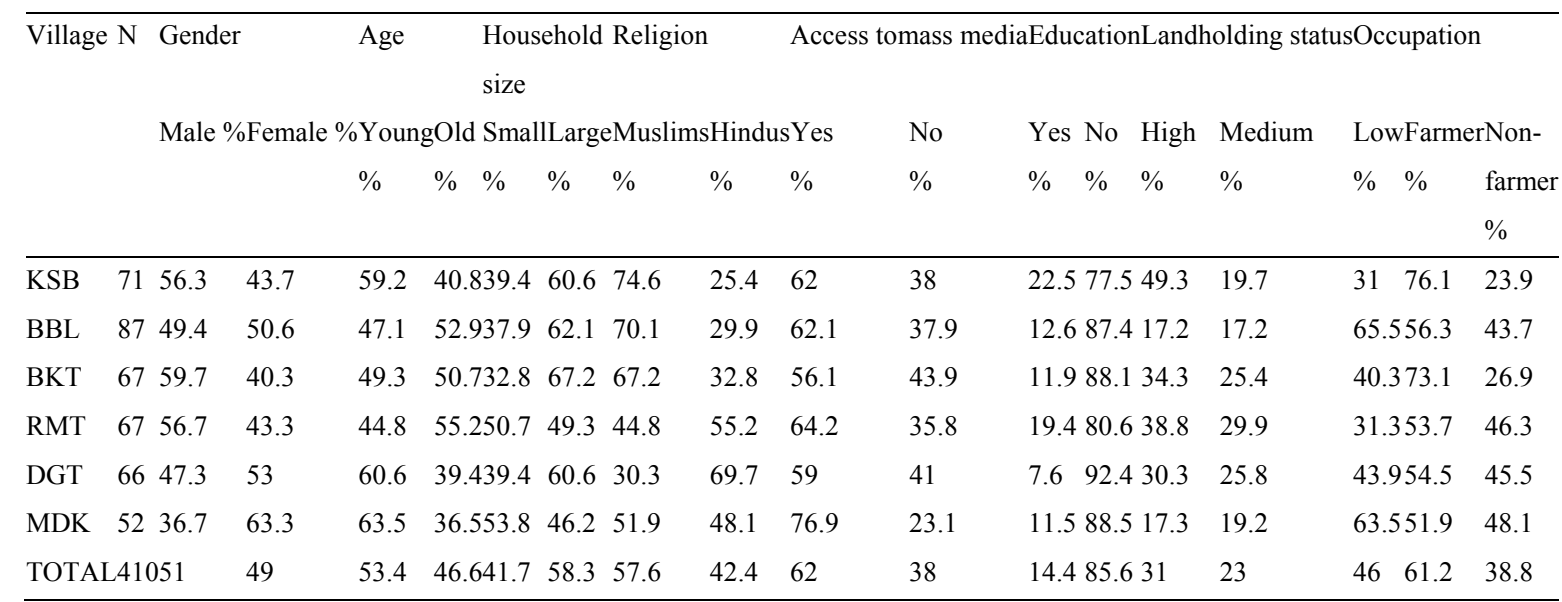

$[\overline{\mathrm{KSB}}=$ Keshabpur, $\mathrm{BBL}=$ Baliadanga, $\mathrm{BKT}=$ Brahmakati, $\mathrm{RMT}=$ Ramchandrapur, $\mathrm{DGT}=$ Durapur, $\mathrm{MDK}=$ Madhyakul].

\subsection{Crop Damage and Human-langur Conflicts}

More than two-thirds (68.5\%) of the respondents reported that crop damage significantly affected human-langur conflicts (Table 2), whereas less than one-fourth (22.9\%) considered household disturbance to be an important factor in human-langur conflicts, and only $8.5 \%$ stated that langurs caused important threats to villagers (Table 2). People from high conservation priority areas differed significantly from those of low conservation priority areas in their opinion regarding current human-langur conflicts. Respondents from low conservation priority areas reported significantly more crop damage than those from high conservation priority areas (Table 2).

Table 2. Distribution of responses $(\mathrm{N}=410)$ in relation to the questions "what is your experience towards human-langur conflicts in the area" and "how locals drive away langurs from crops fields?"

\begin{tabular}{lllllll}
\hline Variables & Experience of Locals & $\begin{array}{l}\text { High conservation } \\
\text { priority areas } \\
(\mathrm{N}=225)\end{array}$ & $\begin{array}{l}\text { Low conservation } \\
\text { priority areas } \\
(\mathrm{N}=185)\end{array}$ & & d.f. $\mathrm{P}=$ \\
& & 62.7 & 75.1 & & \\
\hline $\begin{array}{l}\text { Experience towards } \\
\text { human-langur conflicts }\end{array}$ & Crop damage & & & & & \\
& & & 16.2 & & \\
& Household disturbance & 28.4 & 8.1 & 2 & 0.01 \\
& Threaten people & 8.9 & 24.9 & & & \\
Local deterrent methods & Guarding & 40.4 & 63.2 & & & \\
& Instantaneous & 48.9 & 11.9 & 11.28 & 2 & 0.004 \\
& Miscellaneous & 10.7 & & & \\
\hline
\end{tabular}

Langurs damaged a total of 27 different cultivated crop species, most of which were fruits (Appendix 1). The vast majority $(77.3 \%)$ of the respondents reported that langurs frequently damaged important crops, whereas a minority (26.8 \%) reported crop damage as being insignificant (Table 3). However, the respondents' views regarding crop damage did not differ significantly among the villages (Table 3). In this regard, $79.8 \%$ of individuals in high conservation priority areas and $76.8 \%$ in low conservation priority areas reported that langurs frequently damage crops (Table 3). However, farmers stated that crop damage was more extensive than did non-farmers, and people with a high or intermediate land-holding status experienced more frequent crop damage than those of low landholding status (Table 3). The other tested independent variables did not differ significantly between the groups with regard to how the interviewees assessed the importance of crop damage (Table 3). 
Table 3. Distribution of responses $(\mathrm{N}=410)$ in relation to the question "how important are crops in relation to langur damage in your garden or agricultural field?"

\begin{tabular}{|c|c|c|c|c|c|c|}
\hline \multicolumn{4}{|c|}{ Importance of crop damage } & \multicolumn{3}{|c|}{ Final logistic model } \\
\hline Variables & Important & Intermediate & Unimportant & $\chi^{2}$ & $\mathrm{df}$ & $\mathrm{P}=$ \\
\hline \multicolumn{7}{|l|}{ Villages } \\
\hline High conservation priority area & 77.8 & 14.7 & 7.6 & & & \\
\hline Low conservation priority area & 76.8 & 14.6 & 8.6 & 0.16 & 2 & NS \\
\hline \multicolumn{7}{|l|}{ Gender } \\
\hline Male & 77 & 15.3 & 7.7 & & & \\
\hline Female & 77.6 & 13.9 & 8.5 & 0.22 & 2 & NS \\
\hline \multicolumn{7}{|l|}{ Age } \\
\hline Young & 80.4 & 14.6 & 5 & & & \\
\hline Old & 73.8 & 14.7 & 11.5 & 5.91 & 2 & NS \\
\hline \multicolumn{7}{|l|}{ Household size } \\
\hline Small family & 76 & 15.2 & 8.8 & & & \\
\hline Large family & 78.2 & 14.2 & 7.5 & 0.32 & 2 & NS \\
\hline \multicolumn{7}{|l|}{ Religion } \\
\hline Muslim & 79.2 & 12.3 & 8.5 & & & \\
\hline Hindu & 74.7 & 17.8 & 7.5 & 2.49 & 2 & NS \\
\hline \multicolumn{7}{|l|}{ Access to mass media } \\
\hline No & 76.9 & 13.5 & 9.6 & & & \\
\hline Yes & 77.6 & 15.4 & 7.1 & 1.09 & 2 & NS \\
\hline \multicolumn{7}{|l|}{ Education } \\
\hline Uneducated & 78.1 & 13.4 & 8.5 & & & \\
\hline Educated & 72.9 & 22 & 5.1 & 3.51 & 2 & NS \\
\hline \multicolumn{7}{|l|}{ Landholding status } \\
\hline High & 85.2 & 11.7 & 3.1 & & & \\
\hline Medium & 83.9 & 9.7 & 6.5 & & & \\
\hline Low & 68.8 & 19 & 12.2 & 16.27 & 4 & 0.003 \\
\hline \multicolumn{7}{|l|}{ Occupation } \\
\hline Farmer & 81.3 & 12.4 & 6.4 & & & \\
\hline Non-farmer & 71.1 & 18.2 & 10.7 & 5.87 & 2 & 0.05 \\
\hline
\end{tabular}

Table 4. Distribution of responses $(\mathrm{N}=410)$ in relation to the question "what season do the langurs damage most crops?"

\begin{tabular}{|c|c|c|c|c|c|}
\hline \multirow[b]{2}{*}{ Variables } & \multicolumn{2}{|c|}{ Crop damage in relation to season } & \multicolumn{3}{|c|}{ Final logistic model } \\
\hline & Fruiting season & Throughout year & $\chi^{2}$ & d.f. & $\mathrm{P}=$ \\
\hline \multicolumn{6}{|l|}{ Villages } \\
\hline High conservation priority area & 74.7 & 25.3 & & & \\
\hline Low conservation priority area & 56.2 & 43.8 & 15.5 & 1 & 0 \\
\hline \multicolumn{6}{|l|}{ Gender } \\
\hline Male & 72.7 & 27.3 & & & \\
\hline Female & 59.7 & 40.3 & 7.78 & 1 & 0.005 \\
\hline \multicolumn{6}{|l|}{ Age } \\
\hline Young & 68.9 & 31.1 & & & \\
\hline Old & 63.4 & 36.6 & 1.43 & 1 & NS \\
\hline \multicolumn{6}{|l|}{ Household size } \\
\hline Small family & 64.3 & 35.7 & & & \\
\hline Large family & 67.8 & 32.2 & 0.53 & 1 & NS \\
\hline Religion & & & & & \\
\hline
\end{tabular}




\begin{tabular}{|c|c|c|c|c|c|}
\hline Muslim & 69.5 & 30.5 & & & \\
\hline Hindu & 62.1 & 37.9 & 2.47 & 1 & NS \\
\hline \multicolumn{6}{|c|}{ Access to mass media } \\
\hline No & 70.5 & 29.5 & & & \\
\hline Yes & 63.8 & 36.2 & 1.96 & 1 & NS \\
\hline \multicolumn{6}{|l|}{ Education } \\
\hline Uneducated & 67 & 33 & & & \\
\hline Educated & 62.7 & 37.3 & 0.47 & 1 & NS \\
\hline \multicolumn{6}{|c|}{ Landholding status } \\
\hline High & 68 & 32 & & & \\
\hline Medium & 69.9 & 30.1 & & & \\
\hline Low & 63.5 & 36.5 & 1.36 & 2 & NS \\
\hline \multicolumn{6}{|l|}{ Occupation } \\
\hline Farmer & 70.9 & 40.9 & & & \\
\hline Non-farmer & 59.1 & 32 & 6.04 & 1 & 0.01 \\
\hline
\end{tabular}

Table 5. Distribution of responses $(\mathrm{N}=410)$ in relation to the question "are the local methods effective to deter langurs?"

\begin{tabular}{|c|c|c|c|c|c|}
\hline \multirow[b]{2}{*}{ Variables } & effect & & \multicolumn{3}{|c|}{ Final logistic model } \\
\hline & Yes & No & $\chi^{2}$ & d.f. & $\mathrm{P}$ \\
\hline \multicolumn{6}{|l|}{ Villages } \\
\hline High conservation priority area & 66.7 & 33.3 & & & \\
\hline Low conservation priority area & 49.2 & 50.8 & 12.89 & 1 & $<0.0001$ \\
\hline \multicolumn{6}{|l|}{ Gender } \\
\hline Male & 59.3 & 40.7 & & & \\
\hline Female & 58.2 & 41.8 & 0.053 & 1 & NS \\
\hline \multicolumn{6}{|l|}{ Age } \\
\hline Young & 61.2 & 38.8 & & & \\
\hline Old & 55.5 & 44.5 & 1.36 & 1 & NS \\
\hline \multicolumn{6}{|l|}{ Household size } \\
\hline Small family & 57.9 & 42.1 & & & \\
\hline Large family & 59 & 41 & 0.09 & 1 & NS \\
\hline \multicolumn{6}{|l|}{ Religion } \\
\hline Muslim & 55.1 & 44.9 & & & \\
\hline Hindu & 63.8 & 36.2 & 3.14 & 1 & NS \\
\hline \multicolumn{6}{|l|}{ Access to mass media } \\
\hline No & 49.4 & 50.6 & & & \\
\hline Yes & 64.2 & 35.8 & 9.22 & 1 & 0.002 \\
\hline \multicolumn{6}{|l|}{ Education } \\
\hline Uneducated & 57.3 & 42.7 & & & \\
\hline Educated & 67.8 & 32.2 & 2.43 & 1 & NS \\
\hline \multicolumn{6}{|l|}{ Landholding status } \\
\hline High & 81.2 & 18.8 & & & \\
\hline Medium & 57 & 43 & & & \\
\hline Low & 44.4 & 55.6 & 42.92 & 2 & $<0.0001$ \\
\hline \multicolumn{6}{|l|}{ Occupation } \\
\hline Farmer & 54.2 & 45.8 & & & \\
\hline Non-farmer & 66 & 34 & 5.04 & 1 & 0.017 \\
\hline
\end{tabular}

In addition, the locals stated that langurs eat a variety of their fruits and crops, such as mango, banana, jackfruit, 
and brinjal among others. Moreover, the langurs only eat approximately half of the fruits and damage more than they eat. Finally, villagers are not able to harvest sufficient amounts of the fruits and crops remaining on the trees and/or farms for the purpose of selling them in the market and/or eating them.

In the stepwise regression analysis, only the landholding status of the respondents was found to be significant, although only $4.2 \%$ of the variation in people's perception regarding the importance of crop damage by langurs was explained by this socioeconomic variable (Table 8 ).

\subsection{Seasonal Aspect of Crop Damage}

The majority (65.9\%) of the respondents claimed that langurs cause the greatest amount of damage during the fruiting season (March - July), whereas $34.1 \%$ reported that damage occurred throughout the year (Table 4). However, this view varied significantly among the villages $\left(\chi^{2}=15.47\right.$, d. f. $=1, P=0.000$; Table 3$)$. People in high conservation priority areas experienced higher crop damage during the fruiting season than those in low conservation priority areas (Table 4). Of the respondents experiencing high damage throughout the year (43.8\%), most lived in low conservation priority areas (Table 4). In addition, males and farmers reported significantly more crop damage in the fruiting season than females and non-farmers (Table 4). No significant differences were identified among the respondents' experiences regarding the seasonal aspect of crop damage and the other tested demographic variables (Table 4).

The results of the multivariate analysis indicated that only two variables were significant regarding the respondents' experience of seasonal crop damage as a dependent variable: the level of conservation and gender. However, only $4.5 \%$ of the variation in perception was explained by these two variables (Table 8).

\subsection{Methods for Deterring Langurs from Crop Fields}

More than half (55.4\%) of the respondents practiced immediate deterrent methods (i.e., whenever langurs come to damage crops, the locals attempt to scare them) to drive away langurs from crop fields. This was usually achieved by installing a tin box in a tree with a stick inside attached to a long rope outside that makes a sound when pulled, making loud noises, throwing stones or hard pieces of earth, or actively deterring the langurs with a long piece of bamboo. Almost one-third (33.4\%) of the respondents guarded their crops using school children or day labourers posted as guards. This method of deterrence affected the children's education, resulting in subsequent economic losses. The remainder of the participants (11.1\%) used miscellaneous methods, such as, wrapping fruits particularly for banana, guava, jackfruit, and papaya in thick socks, netting whole trees (specially for mango and litchi), hanging a scarecrow, using dogs, spraying insecticides (particularly for mango) and fencing gardens with sharp barbed iron wire. The use of deterrent methods was not the same in villages in the two conservation status categories, and this difference was statistically significant $\left(\chi^{2}=11.28\right.$, d.f. $\left.=2, P=0.004\right)$ (see Table 2). People in low conservation priority areas mostly preferred to use immediate deterrent methods, whereas guarding was more common in high conservation priority areas (Table 2).

The majority (58.8\%) of the respondents stated that the measures that were taken to control langur damage were effective; that is in most cases, they were able to deter langurs and save crops. However, this opinion differed significantly between the villages in the two conservation status categories $\left(\chi^{2}=12.89\right.$, d.f. $\left.=1, P=0.000\right)$ (Table 5). Positive opinions towards deterrent measures were higher in high conservation priority areas than in low conservation priority areas (Table 5). People with access to mass media, those with a high landholding status, and non-farmers also reported positive effects of local deterrent methods more frequently than their respective counterparts (Table 5). However, the locals added also that the measures taken to drive away langurs from their farmlands were painful, time consuming, and costly. Despite these measures, langurs still occasionally ate fruits and crops from gardens.

In the stepwise linear regression analysis, four variables (the level of conservation, religion, landholding status, and the occupation of the respondents) were found to be statistically significant predictors, explaining $20.5 \%$ of the variation in people's opinion about the effectiveness of local deterrent methods (Table 8).

\subsection{Ability to Tolerate Crop Damage}

Approximately $59 \%$ of the respondents agreed that they were be able to tolerate crop damage, while $41 \%$ showed no tolerance towards crop damage caused by langurs. The difference in the respondents' tolerance varied significantly between the villages (Table 6). Respondents from high conservation priority areas showed a higher level of tolerance towards crop damage than those from low conservation priority villages (Table 6), and Hindus were more tolerant than Muslims. People with access to mass media, those with a high landholding status, and non-farmers were also more tolerant towards crop damage than their counterparts without access to mass media and those having intermediate or low landholding status (Table 6). 
Table 6. Distribution of responses $(\mathrm{N}=410)$ in relation to the question "do you tolerate crop damage?"

\begin{tabular}{llllll}
\hline & Tolerate crop damag & \multicolumn{5}{c}{ Final logistic model } \\
Variables & Yes & No & $\chi^{2}$ & d.f. & P \\
\hline Villages & & & & & \\
$\quad$ High conservation priority area & 66.7 & 33.3 & & & \\
$\quad$ Low conservation priority area & 49.7 & 50.3 & 12.04 & 1 & 0.001 \\
Gender & & & & & \\
$\quad$ Male & 60.3 & 39.7 & & & \\
$\quad$ Female & 57.7 & 42.3 & 0.28 & 1 & NS \\
Age $\quad$ & & & & & \\
$\quad$ Young & 61.2 & 38.8 & & & \\
$\quad$ Old & 56 & 44 & 1.33 & 1 & NS \\
Household size & & & & & \\
$\quad$ Small family & 58.5 & 41.5 & & & \\
$\quad$ Large family & 59.4 & 40.6 & 0.01 & 1 & NS \\
Religion & & & & & \\
$\quad$ Muslim & 55.1 & 44.9 & & & \\
$\quad$ Hindu & 64.4 & 35.6 & 3.59 & 1 & 0.05 \\
Access to mass media & & & & & \\
$\quad$ No & 52 & 48 & & & \\
$\quad$ Yes & 64.2 & 35.8 & 8.01 & 1 & 0.004 \\
Education & & & & & \\
$\quad$ Not educated & 57.3 & 42.7 & & & \\
$\quad$ Educated & 67.8 & 32.2 & 2.19 & 1 & NS \\
Landholding status & & & & & \\
$\quad$ High & 52.8 & 17.2 & & & \\
$\quad$ Medium & 57 & 43 & & & \\
$\quad$ Low & 43.9 & 56.1 & 47.92 & 2 & $<0.0001$ \\
Occupation & & & & & \\
$\quad$ Farmer & 54.6 & 45.4 & & & \\
$\quad$ Non-farmer & 66 & 34 & 5.28 & 1 & 0.02 \\
\hline$\quad$ & & & & \\
$\quad$ & & & & &
\end{tabular}

In the stepwise linear regression analysis, $21.8 \%$ of the variation in people's perceptions with respect to tolerance to crop damage could be attributed to the combined effect of four independent variables: the level of conservation, religion, landholding status and the occupation of the respondents (Table 8).

\subsection{Local Opinion Regarding the Responsibility of the Forest Department towards Langurs}

The majority $(85 \%)$ of the respondents stated that the strategy implemented to minimize crop damage and conserve common langurs (the 'Biodiversity Conservation and Natural Development Project' for supplying food to the langurs) was ineffective and had no significant impact on crop damage, while only $15 \%$ of the respondents claimed it was appropriate. However, this opinion differed significantly between the villages (Table 8). Positive attitudes towards the strategy were more frequently found among the respondents living in high conservation priority areas (Table 7). Educated respondents having a high landholding status and those who were non-farmers rated the strategy as appropriate (Table 8). The other independent variables had no significant effect on this perception (Table 8).

The stepwise linear regression analysis revealed that the level of conservation, education and the occupation of the respondents were significant variables, although they explained only $5.6 \%$ of the variation in people perceptions of the conservation project (Table 8). 
Table 7. Distribution of responses $(\mathrm{N}=410)$ in relation to the question "what is your opinion about the management strategy taken by the forest department to minimize crop damage?"

\begin{tabular}{|c|c|c|c|c|c|}
\hline \multirow{2}{*}{$\begin{array}{l}\text { Management strategy } \\
\text { Variables }\end{array}$} & \multicolumn{3}{|c|}{ Final logistic model } & \multirow[b]{2}{*}{ d.f. } & \multirow[b]{2}{*}{$\mathrm{P}$} \\
\hline & Appropriate & Poor & $\chi^{2}$ & & \\
\hline \multicolumn{6}{|l|}{ Villages } \\
\hline High conservation priority area & 21.3 & 78.7 & & & \\
\hline Low conservation priority area & 8.1 & 91.9 & 13.65 & 1 & $<0.0001$ \\
\hline \multicolumn{6}{|c|}{ Gender } \\
\hline Male & 15.8 & 84.2 & & & \\
\hline Female & 14.9 & 85.1 & 0.05 & 1 & NS \\
\hline \multicolumn{6}{|l|}{ Age } \\
\hline Young & 14.6 & 85.4 & & & \\
\hline Old & 16.2 & 83.8 & 0.2 & 1 & NS \\
\hline \multicolumn{6}{|l|}{ Household size } \\
\hline Small family & 14 & 86 & & & \\
\hline Large family & 16.3 & 83.7 & 0.39 & 1 & NS \\
\hline \multicolumn{6}{|l|}{ Religion } \\
\hline Muslim & 17.4 & 82.6 & & & \\
\hline Hindu & 12.6 & 87.4 & 1.72 & 1 & NS \\
\hline \multicolumn{6}{|l|}{ Access to mass media } \\
\hline No & 14.7 & 85.3 & & & \\
\hline Yes & 15.7 & 84.3 & 0.07 & 1 & NS \\
\hline \multicolumn{6}{|l|}{ Education } \\
\hline Uneducated & 13.4 & 86.6 & & & \\
\hline Educated & 27.1 & 72.9 & 7.32 & 1 & 0.007 \\
\hline \multicolumn{6}{|l|}{ Landholding status } \\
\hline High & 21.1 & 78.9 & & & \\
\hline Medium & 7.5 & 92.5 & & & \\
\hline Low & 15.3 & 84.7 & 7.62 & 2 & 0.02 \\
\hline \multicolumn{6}{|l|}{ Occupation } \\
\hline Farmer & 12.4 & 87.6 & & & \\
\hline Non-farmer & 20.1 & 79.9 & 4.52 & 1 & 0.03 \\
\hline
\end{tabular}

Table 8. Results of stepwise regression analyses of the effects of the independent variables village, gender, religion, education, occupation and landholding status of the respondents and different opinions of locals regarding determining crop damage and human langur conflicts as dependent variables $\left({ }^{*} \mathrm{P}<0.05, * * \mathrm{P}<0.01\right.$, $* * * \mathrm{P}<0.001)$

\begin{tabular}{|c|c|c|c|c|c|}
\hline $\begin{array}{l}\text { Independent } \\
\text { variables }\end{array}$ & $\begin{array}{l}\text { Importance of } \\
\text { crop damage } \\
\text { t-value }\end{array}$ & $\begin{array}{l}\text { Seasonal } \\
\text { crop damage } \\
\text { t-value }\end{array}$ & $\begin{array}{l}\text { Effectiveness of the } \\
\text { applied measures } \\
\text { t- value }\end{array}$ & $\begin{array}{l}\text { Tolerance of } \\
\text { crop damage } \\
\text { t-value }\end{array}$ & $\begin{array}{l}\text { Opinion regarding } \\
\text { management strategy } \\
\text { t-value }\end{array}$ \\
\hline $\begin{array}{l}\text { Conservation } \\
\text { level }\end{array}$ & 0.22 & $4.25^{* * *}$ & $-5.59^{* * *}$ & $5.57^{* * *}$ & $-3.85^{* * *}$ \\
\hline Gender & -0.9 & $2.82 * *$ & -0.02 & -0.33 & -0.2 \\
\hline Religion & -0.16 & 0.26 & $3.94 * * *$ & $4.16^{* * *}$ & -0.25 \\
\hline Education & 0.17 & 0.69 & 0.5 & 0.42 & $2.05^{*}$ \\
\hline Occupation & 1.57 & $1.94 *$ & $4.51 * * *$ & $4.60^{* * *}$ & $2.77 * *$ \\
\hline $\begin{array}{l}\text { Landholding } \\
\text { status }\end{array}$ & 3.41 & 0.73 & $-8.58^{* * *}$ & $-9.05 * * *$ & -1.62 \\
\hline Constant & $5.25^{*}$ & $2.12 *$ & $6.75^{* * *}$ & $6.93 * * *$ & 1.82 \\
\hline $\mathrm{R}^{2}$ & 0.02 & 0.08 & 0.2 & 0.21 & 0.05 \\
\hline
\end{tabular}




\section{Discussion}

\subsection{Crop Damage and Human-langur Conflicts}

The majority of the respondents claimed that crop raiding by langurs was the most significant issue in the human-langur conflicts in the study area. The adaptations, opportunistic feeding behaviour, ecology, and intelligence of primates result in these species being considered to represent important crop raiders (Mittermeier \& Cheney, 1987).

Subsistence farmers and those owning less land individually suffer higher economic losses through crop damage caused by wildlife, and their attitudes are therefore negative towards the crop-raiding species (Priston, 2005; Rao, Maikhuri, Nautiyal \& Saxena, 2002; Sekhar, 1998). In accord with earlier findings, the present study revealed significant relationships between the experiences of respondents in relation to crop damage as well as their occupation and landholding status. Farmers and non-farmers presented opposite views towards crop damage by langurs reducing harvests. Subsistence farmers reported more extensive damage than did non-farmers. Contrary to the above-mentioned findings, people with a high or intermediate landholding status reported that crop damage was more important than those of low landholding status. A possible explanation for this finding might be that farmers with a high or intermediate landholding status owned more cultivated gardens and/or farms, and therefore, they suffered crop damage more frequently than their counterpart of low landholding status.

\subsection{Seasonal Aspect of Crop Damage}

The relationship between temporal forest fruiting patterns and crop raiding by wildlife is highly complex in tropical regions (Chiyo, Cochrane, Naughton, \& Basuta, 2005). Some fruits and plants were raided throughout the year due to exhibiting no definite fruiting season (e.g., banana and papaya in Java (Soemarwoto, Soemarwoto, Karyono, \& Ramlan, 1985); cassava in Sumatra (Nyhus, Tilson, \& Sumianto, 2000); immature coconut in Zanzibar (Siex \& Struhsaker, 1999); arena palm in Indonesia (Riley, 2007)). However, most fruits (cempedak, jenhko, durian, and petai) were found to be vulnerable mainly during the peak fruiting season (May - August) in Sumatra (Marchal \& Hill, 2009). The present study similarly found both strong seasonality and non-seasonality in the temporal patterns of crop damage caused by langurs. Fruits such as, mango, jackfruit, guava, black berry, and litchi were mostly damaged during the fruiting season, whereas other types of fruit (e.g., banana, papaya, sapodilla, hog plum, and immature coconut) were damaged throughout the year. This suggests that the crop-raiding patterns by langurs in Keshabpur might be determined by seasonal aspects of the available human-edible fruits, rather than by the scarcity of foods, as observed in several previous studies (e.g., (Beasley \& Rhodes, 2008; Chiyo, Cochrane, Naughton, \& Basuta, 2005; Sukumar, 1989).

\subsection{Langur Deterrence Methods and their Effectiveness}

Both active deterrent techniques and miscellaneous methods were reported to be effective in deterring langurs. In earlier studies, the use of active deterrent methods to reduce crop damage has varied among raiding species and areas, for example, shooting and/or trapping primates used as successful methods in Telega Said and were rarely used at Tangkahan and Bukit Lawang in Sumatra (Marchal \& Hill, 2009); thorny shrub fences for wild boars and chili grease fences for African elephants (Sitati \& Walpole, 2006); retribution killings and setting snare traps around Kerici Seblat National Park in Sumatra for wildlife including tigers (Martyr \& Nugraha, 2004); retribution killing for orangutans in Sumatra on rare occasions (Campbell-Smith, Simanjorang, Leader-Williams, \& Linkie, 2010); killing, consumption or sale occurred rarely in Telega Said and Kerici Seblat National Park, Sumatra for pig-tailed macaques and wild boars (Linkie, Dinata, Nofrianto, \& Leader-Williams, 2007).

Studsrød and Wegge (1995) and Sitai and Walpole (2006) reported that guarding was a successful measure for controlling crop damage caused by raiding wildlife species. However, guarding might sometimes lead to human injuries (Hill, 2004; Marchal \& Hill, 2009) and/or kidnapping of wild animals (Riley \& Priston, 2010). However, no instances of retribution killing, shooting, and/or trapping of langurs to prevent crop raiding was reported during the present study period as the local people, especially the Hindus regard them as sacred animals. The positive findings of this study might be used as a basic protocol for the conservation of common langurs in the study areas. However, in relation to the protection of these langurs, little information is available about the use of insecticides during the fruiting season, especially for mangoes, as mango tree owners spray insecticides to safeguard their crops. Thus, obtaining this information is also important. If we ignore the respondents' interest in spraying insecticides, the common langurs' future survival in the study areas might be jeopardized.

\subsection{Tolerance of Crop Damage}

The majority of the respondents (59\%) were tolerant towards the crop damage inflicted by langurs. Their perceptions regarding crop damage appeared to be related to the level of the applied conservation program, 
religion, landholding status, and the occupation of the respondents. People who received a low level of benefits from the conservation programs were more likely to be tolerant towards crop damage than their counterparts. Additionally, Hindus were more tolerant to crop damage than Muslims. This may be because the local Hindus were mostly engaged in non-farming activities and because of their religious affiliation, in which langurs are considered to be sacred. In addition, farmers who owned little land were less tolerant towards langurs (Priston, 2005).

Human-langur conflicts in the area are not pronounced, because a sizeable langur population has resided in vast homestead vegetation areas of the Keshabpur UP and thus, villagers are somewhat habituated to coexist with this species. However, signs of danger are beginning to appear as the increasing human population invades langur habitats, resulting in the loss of large trees and transformation of homestead forest/vegetation into farmlands. Therefore, langurs are facing a scarcity of food and shelter. As a result, human-langur conflicts are increasing, or will increase, due to joint use of resources. The majority of the respondents to the survey conducted in the present study tolerate crop damage; nevertheless, the views of the minority should not be ignored. The factors associated with the promotion of local tolerance towards damage caused by langurs are specially important with respect to developing mitigation protocols providing tangible solutions for minimizing human-langur conflicts in the study areas, as similar to protocols accepted in many other parts of the world (Fuentes, Southern, \& G., 2005; Hill, 2004; Hockings \& Humle, 2009; Lee \& Priston, 2005; Paterson, 2005).

Further studies are recommended in Bangladesh and elsewhere to determine the extent of the actual loss of crops caused by primates versus what is perceived by the farmers. Targeted conservation education programs represent a promising option for achieving this goal and should be initiated to increase local awareness regarding the future survival of the species in this area. Furthermore, we propose that more food trees of langurs should be planted, such as rain trees (Samanea saman), ipil ipil (Leucaena leucocephala), cotton trees (Salmalia malabarica), horse radish tree, 'debdaru' (Polylthia longifolia), tamarind (Tamarindus indica), 'dewa' (Artocarphus lacucha), black berries, banana, papaya, hog plum, bean, long bean, peas, pulses, and tree potato (Dioscorea sp.) in Government 'khas' land around langur habitats to achieve multi-layered agro-forest homestead vegetation. This type of vegetation will also be useful for locals as an extractive resource reserve. The conservation value of such human-constructed niches for primates has been observed in the Neotropics, for instance, tamarins (Raboy, Christman, \& Dietz, 2004) and howler monkeys (Williams-Guillén, McCann, Martinez Sanchez, \& Koontz, 2006), and such niches are increasingly emerging in South Asia (Bali, Kumar \& Krishnaswamy, 2007).

\section{Conclusion}

The common langur, Semnopithecus entellus (Dufresne, 1797), is one of the most endangered colobine primates (Anon, 2003) in Bangladesh. This species resides mainly in six villages of the Keshabpur Upazila in the Jessore district of Bangladesh. However, concern is growing regarding crop damage caused by these langurs and the consequent human-langur conflicts in the area. Langurs damage a total of 27 cultivated crops, among which the majority are fruits, and the greatest amount of damage occurs during the fruiting season (March - July). Most of the respondents $(77 \%)$ to the survey carried out in the present study perceived crop damage by langurs to be an important factor in the reduction of harvests. People who had a high or intermediate landholding status stated crop damage to be more severe compared with their counterparts. Approximately $59 \%$ of the respondents showed tolerance towards damage caused by langurs. Specifically, Hindus were relatively more tolerant than Muslims and non-farmers with a high landholding status having access to mass media showed a greater tolerance than farmers with a intermediate or low landholding status and no access to mass media. Locals stated that the Forest Department and its officials are not exerting sufficient effort regarding this issue, and they are not caring that much. The majority of the respondents $(87 \%)$ stated that the strategy used by the Forest Department to minimize crop damage was poor. Educated and non-farmer respondents with a high landholding status living in high conservation priority areas had a more positive attitude towards the strategy taken by the Forest Department for the conservation of the langurs.

\section{Acknowledgements}

We thank the NUFU (Norwegian Council of Universities' Committee for Development Research and Education) funded Project 'Ecology Behavior and Conservation of Some Wildlife of Bangladesh' for financial support to conduct this research. We are grateful to our field assistants for their amiable assistance and help during the field work. A special thank goes to Professor Dr. M. A. Gofur Khan for his valuable comments on an earlier draft of this manuscript. The authors would like to thank the local administration and the people of Keshabpur upazila for their friendly assistance, tolerance and helpfulness throughout the study period. All data collections followed 
the ethical guidelines of the Bangladesh Government. Permission was given from the Forest Department under the Ministry of Environment and Forest, Bangladesh. The authors declare they have no conflict of interest. Finally we want to acknowledge four anonymous referees for commends that improved the paper.

\section{References}

Agetsuma, N. (2007). Ecological function losses caused by monotonous land use induce crop raiding by wildlife on the island of Yukushima, Southern Japan. Ecological Reserve, 22, 390-402. http://dx.doi.org/10.1007/s11284-007-0358-z

Ahsan, M. F., \& Khan, M. A. R. (2006). Eco-ethology of the common langur Semnopithecus entellus (Dufresne) in Bangladesh. University Journal of Zoology, 25, 3-10.

Anon. (2003). Banglapedia. In National Encyclopedia of Bangladesh. Dhaka: Asiatic Society of Bangladesh.

Aziz, M. A., Feeroz, M. M., \& Shahriar, A. F. M. (2005). Feeding movements of the Asian elephants in the Northern side of the River Karnaphuli in the Chittagong Hill Tracts, Bangladesh. Bangladesh Journal of Life Science, 17, 51-58.

Bali, A., Kumar, A., \& Krishnaswamy, J. (2007). The mammalian communities in coffee plantations around a protected areas in the Western Ghat, India. Biological Conservation, 139, 99-102. http://dx.doi.org/10.1016/j.biocon.2007.06.017

BBS. (2009). Statistical year book. Government of People's Republic of Bangladesh.

Beasley, J. C., \& Rhodes, J. O. E. (2008). Relationship between raccoon abundance and crop damage. Human Wildlife Conflicts, 2(2), 248-259.

Boulton, A. M., Horrocks, J. A., \& Baulu, J. (1996). The Barbados vervet monkey (Cercopithecus acthiops sabacus): Changes in population size and crop damage 1980-1994. International Journal of Primatilogy, 17, 831-844. http://dx.doi.org/10.1007/BF02735267

Campbell-Smith, G., Simanjorang, H. V. P., Leader-Williams, N., \& Linkie, M. (2010). Local attitudes and perceptions toward crop-raiding by orangutans (Pongo abelii) and other nonhuman primates in Northern Sumatra, Indonesia. American Journal of Primatology, 72(10), 866-876. http://dx.doi.org/10.1002/ajp.20822

Chhangani, A. K., \& Mohnot, S. M. (2004). Crop raid by hanuman langur Semnopithecus entellus in and around Aravallis, (India) and management. Primate Repor, 69, 35-47.

Chivers, D. J. (1986). Feeding and ranging in gibbons; a summary. The lesser apes: evolutionary and behavioural biology. In H. Preuschoft, D. J. Chivers, W. Brocklerman, \& N. M. Creel, (Eds.) (pp. 267-281) Edinburgh, UK: Edinburgh University Press.

Chiyo, P. I., Cochrane, E. P., Naughton, L., \& Basuta, G. I. (2005). Temporal patterns of crop raiding by elephants: a response to changes in forage quality or crop availability? African Journal of Ecology, 43(1), 48-55. http://dx.doi.org/10.1111/j.1365-2028.2004.00544.x

Cowlishaw, G., \& Dunbar, R. (2000). Primate conservation biology. London, UK: University of Chicago Press Ltd.

Dela, J. D. S. (2004). Protecting the endemic purple faced langur. Loris, 23, 14-22.

Dela, J. D. S. (2007). Seasonal food use strategies of Semnopithecus vetulus nestor, at Panadura and Piliyandala, Sri Lanka. International Journal of Primatology, 28, 607-626. http://dx.doi.org/10.1007/s10764-007-9150-8

Dupain, J., \& Elsacker, V. (2001). The status of bonobo (Pan paniscus) in the Democratic Republic of Congo. All apes great and small. Vol 1: African apes. In B. M. F. Galdikas, N. Erickson Briggs, L. K. Sheeran, G. L. Shapiro \& J. Goodall ( Eds.) (pp. 75-82). New York, USA: Kluwer Academic/Plenum Publishers.

Feeroz, M. M., Aziz, M. A., Islam, M. T., \& Islam, M. A. (2003). Human-elephant conflicts in Southeastern hilly areas of Bangladesh. Proceedings of the Symposium on Human-Elephant Relationships and Conflicts, Colombo, Sri Lanka, 2003.

Forthman-Quick, D. L. (1996). Activity Budgets and the Consumption of Hanuman Foods in two Troops of Baboons (Papio anubis) at Agilgil, Kenya. Primate Ecology and Conservation. In J. G. Else, \& P. C. Lee, (Eds.). (pp. 221-228). New York, USA: Cambridge University Press.

Fuentes, A., Southern, M., \& G., S. K. (2005). Monkey forests and human landscapes: is extensive sympatry sustainable for Homo sapiens and Macaca fascicularis on Bali? In Commensalism and conflict: the 
human-primate interface. In J. D. Paterson \& J. Wallis (Eds.). (pp. 169-195). Norman: American Society of Primatology.

Gautier, J. P., \& Biquand, S. (1994). Primate commensalism. Revue D Ecologie-La Terre Et La Vie, 49, 210-212.

Hill, C. M. (1997). Crop-raiding by wild vertebrates: the farmer's perspective in an agricultural community in Western Uganda. International Journal of Pest Management, 43(11), 77-84. http://dx.doi.org/10.1080/096708797229022

Hill, C. M. (1998). Conflicting attitudes towards elephants around the Budongo Forest Reserce, Uganda. Environmental Conservation, 26, 218-228.

Hill, C. M. (2000). Conflict of interest between people and baboons: crop raiding in Uganda. International Journal of Primatology, 21(2), 299-315. http://dx.doi.org/10.1023/A:1005481605637

Hill, C. M. (2004). Farmer's perspectives of conflict at the wildlife-agriculture boundary: some lessons learned from African subsistence farmers. Human Dimensions of Wildlife, 9, 279-286. http://dx.doi.org/10.1080/10871200490505710

Hill, C. M. (2005). People, crops and primates: a conflict of interests. Commensalism and conflict: the human-primate interface. In J. D. Paterson \& J. Wallis (Eds). (pp. 40-59). Norman: American Society of Primatology.

Hockings, K., \& Humle, T. (2009). Best practice guidelines for the preventation mitigation of conflict between humans and great apes. IUCN/SSC Primate Specialist Group (PSG). http://dx.doi.org/10.2305/IUCN.CH.2009.SSC-OP.37.en

Hockings, K. J. (2007). Human-chimpanzee coexistence at Bossou the Republic of Guinea: a chimpanzee perspective. Stirling, Scotland: University of Stirling.

Horrocks, J. A., \& Baulu, J. (1994). Food competition between vervets (Cercopithecus aethiops sabaeus) and farmers in Barbados: implications for management. Revue D Ecologie-La Terre Et La Vie, 49, 281-294.

Islam, M. A., \& Al Zabed, A. (1992). Man-elephant interaction at Chunati wildlife sanctuary in Bangladesh. IUCN/SSC Commission.

IUCN. (2009). IUCN Red list of threatened species. Retrieved accessed 22 November 2009.

Khatun, M. U. H. (2012). Eco-ethology, conflict with human and conservation issues on the common langur (Semnopithecus entellus) in Bangladesh PhD, Department of Zoology, University of Chittagong.

Lahm, S. A. (1996). A nationwide survey of crop-raiding by elephants and other species in Gabon. Pachyderm, 21, 69-77.

Lee, P. C., \& Priston, N. J. (2005). Human attitudes to primates: Perception of pests, conflict and consequences for primate conservation. Primate: Human interaction and conservation. In J. D. Patterson \& J. Wallace (Eds.). Toronto, Canada: American Society of Primatologists Publications.

Linkie, M., Dinata, Y., Nofrianto, A., \& Leader-Williams, N. (2007). Patterns and perceptions of wildlife crop raiding in and around Kerinci Seblat National Park, Sumatra. Animal Conservation, 10(1), 127-135. http://dx.doi.org/10.1111/j.1469-1795.2006.00083.x

Marchal, V., \& Hill, C. (2009). A study of local perceptions in four villages in North Sumatra, Indonesia. Primate Conservation, 24, 107-116. http://dx.doi.org/10.1896/052.024.0109

Martyr, D. J., \& Nugraha, R. T. (2004). Kerici Seblat tiger protection. Fauna and Flora International and Kerici Seblat National Park.

Miah, D. M., Rahman, L. M., \& Ahsan, M. F. (2001). Assessment of crop damage by wildlife in Chunati Wildlife Sanctuary, Bangladesh. Tiger Paper, 28, 22-28.

Mittermeier, R. A., \& Cheney, D. L. (1987). Conservation of primates and their habitats. Primate societies. In B. B. Smuts, D. L. Cheney, R. M. Seyfarth, R. W. Wrangham \& T. T. Struhsaker (Eds.) (pp. 477-490). Chicago, Ill, USA: University of Chicago Press.

Myers-Thompson, J. A. (2001). The status of bonobos in their southernmost geographic range. All apes great and small. Vol 1: African apes. In B. M. F. Galdikas, N. Erickson Briggs, L. K. Sheeran, G. L. Shapiro \& J. Goodall (Eds.). (pp. 75-82). New York, USA: Kluwer Academic/Plenum Publishers.

Naughton-Treves, L. (1998). Predicting patterns of crop damage by wildlife around Kibale National Park, 
Uganda. Conservation Biology, 12(1), 156-168. http://dx.doi.org/10.1046/j.1523-1739.1998.96346.x

Naughton-Treves, L., Treves, A., Chapman, C., \& Wrangham, R. (1998). Temporal patterns of crop-raiding by primates: linking food availability in croplands and adjacent forest. Journal of Applied Ecology, 35(4), 596-606. http://dx.doi.org/10.1046/j.1365-2664.1998.3540596.x

Nyhus, P. J., Tilson, R., \& Sumianto, P. (2000). Crop-raiding elephants and conservation implications at Way Kambas National Park, Sumatra, Indonesia. Oryx, 34(4), 262-274. http://dx.doi.org/10.1046/j.1365-3008.2000.00132.x

Paterson, J. D. (2005). Residents and immigrants: reactions and perceptions of crop raiding in Misindi District, Uganda. Commensalism and conflict: the human-primate Interface. In J. D. Paterson, \& J. Wallis (Eds.). (pp. 76-89). Norman: American Society of Primatology.

Pirta, R. S., Gadgil, M., \& Kharshikar, A. V. (1997). Management of the rhesus monkey, Macaca mulatta and hanuman langur Presbytis entellus in Himachal Pradesh, India. Biological Conservation, 79, 97-106. http://dx.doi.org/10.1016/0006-3207(95)00131-X

Priston, N. E. C. (2005). Crop raiding by Macaca ochreata brunnescens in Sulawesi: reality, perceptions and outcomes for conservations, University of Cambridge.

Raboy, B. E., Christman, M. C., \& Dietz, J. M. (2004). The use of degraded and shade cocoa forests by endangered golden-headed lion tamarins Leontopithecus chrysomelas. Oryx, 38(1), 75-83. http://dx.doi.org/10.1017/S0030605304000122

Rao, K. S., Maikhuri, R. K., Nautiyal, S., \& Saxena, K. G. (2002). Crop damage and livestock depredation by wildlife: a case study from Nanda Devi Biosphere Reserve, India. Journal of Environmental Management, 66(3), 317-327. http://dx.doi.org/10.1016/S0301-4797(02)90587-6

Reynolds, V. ( Ed.). (2005). The chimpanzees of the Bodungo Forest: Ecology, behaviour and Conservation. Oxford, UK: Oxford University Press.

Riley, E. P. (2007). The human-macaque interface: conservation implications of current and future overlap and conflict in Lore Lindu National park, Sulawesi, Indonesia. American Anthropology, 109, 473-484. http://dx.doi.org/10.1525/aa.2007.109.3.473

Riley, E. P., \& Priston, N. E. C. (2010). Macaques in farms and folklore: exploring the human-non-human primate interface in Sulawesi, Indonesia. American Journal of Primatology, 72, 848-854. http://dx.doi.org/10.1002/ajp.20798

Saj, T. L., Sicotte, P., \& Paterson, J. D. (2001). The conflict between vervet monkeys and farmers at forest edge in Entebbe, Uganda. African Journal of Ecology, 39(2), 195-199. http://dx.doi.org/10.1046/j.0141-6707.2000.00299.x

Sarker, A. H. M. R., \& Røskaft, E. (2010). Human attitudes towards conservation of Asian elephants (Elephas maximus) in Bangladesh. International Journal of Biodiversity and Conservation, 2(10), 316-327.

Sarker, A. H. M. R., \& Røskaft, E. (2011a). Human-wildlife conflicts and management options in Bangladesh with speicial reference to Asian elephants (Elephas maximus). International Journal of Biodiversity Science, Ecosystem Services \& Management, 6(3), 164-175. http://dx.doi.org/10.1080/21513732.2011.554867

Sarker, A. H. M. R., \& Røskaft, E. (2011b). Human attitudes towards the conservation of protected areas: a case study from four protected areas in Bangladesh. Oryx, 45(3), 391-400. http://dx.doi.org/10.1017/S0030605310001067

Sekhar, N. U. (1998). Crop and livestock depredation caused by wild animals in protected areas: the case of Sariska Tiger Reserve, Rajasthan, India. Environmental Conservation, 25(2), 160-171. http://dx.doi.org/10.1017/S0376892998000204

Siex, K. S., \& Struhsaker, T. T. (1999). Ecology of the Zanzibar red colobus monkey: Demographic variability and habitat stability. International Journal of Primatology, 20(2), 163-192. http://dx.doi.org/10.1023/A:1020558702199

Sitati, N. W., \& Walpole, M. J. (2006). Assessing farm-based measures for mitigating human-elephant conflict in Transmara District, Kenya. Oryx, 40(3), 279-286. http://dx.doi.org/10.1017/S0030605306000834

Soemarwoto, O., Soemarwoto, I., Karyono, S., \& Ramlan, A. (1985). The Javanese home garden as an integrated agrosystem. In Food and Nutrition Bulletin 7: The United Nations University Press. 
Strum, S. C. (1994). Prospects for managements for primate pests. Revue d'écologie: la terre et la vie, 49 , 295-306.

Studsrød, J. E., \& Wegge, P. (1995). Park-people relationships - the case of damage caused by park animals around the Royal Bardia National Park, Nepal. Environmental Conservation, 22, 133-142. http://dx.doi.org/10.1017/S0376892900010183

Sukumar, R. (1989). The Asian elephant-ecology and management. Cambridge, UK: Cambridge University Press.

Tweheyo, M., Hill, C. M., \& Obua, J. (2005). Patterns of crop raiding by primates around the Budongo Forest $\begin{array}{lllll}\text { Reserve, } & \text { Uganda. } & \text { Wildlife } & \text { Biology, } & 11(3),\end{array}$ http://dx.doi.org/10.2981/0909-6396(2005)11[237:POCRBP]2.0.CO;2

Webber, A. D., Hill, C. M., \& Reynolds, V. (2007). Assessing the failure of a community-based human-wildlife conflict mitigation project in Budongo Forest Reserve, Uganda. Oryx, 41(2), 177-184. http://dx.doi.org/10.1017/S0030605307001792

Williams-Guillén, K., McCann, C., Martinez Sanchez, J. C., \& Koontz, F. (2006). Resource availability and habitat use by mantled howling monkeys in a Nicaraguan coffee plantation: can agroforests serve as core habitat for a forest mammal? Animal Conservation, 9, 331-338. http://dx.doi.org/10.1111/j.1469-1795.2006.00042.x 